\title{
Long-term follow-up in a Chinese child with congenital lipoid adrenal hyperplasia due to a StAR gene mutation
}

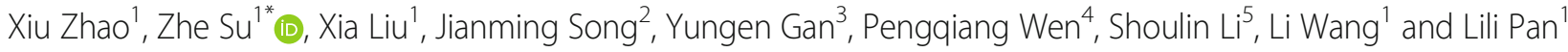

\begin{abstract}
Background: Congenital lipoid adrenal hyperplasia (CLAH) is an extremely rare and the most severe form of congenital adrenal hyperplasia. Typical features include disorder of sex development, early-onset adrenal crisis and enlarged adrenal glands with fatty accumulation.

Case presentation: We report a case of CLAH caused by mutations in the steroidogenic acute regulatory protein (StAR) gene. The patient had typical early-onset adrenal crisis at 2 months of age. She had normal-appearing female genitalia and a karyotype of $46, X Y$. The serum cortisol and adrenal steroids levels were always nearly undetectable, but the adrenocorticotropic hormone levels were extremely high. Genetic analysis revealed compound heterozygous mutations at c. 229 C > T (p.Q77X) in exon 3 and c. 722C > T (p.Q258X) in exon 7 of the StAR gene. The former mutation was previously detected in only two other Chinese CLAH patients. Both mutations cause truncation of the StAR protein. The case reported here appears to be a classic example of CLAH with very small adrenal glands and is the second reported CLAH case with small adrenal glands thus far. In a 15-year follow-up, the patient's height was approximately average for females before age 4 and fell to -1 SDS at 10 years of age. Her bone age was similar to her chronological age from age 4 to age 15 years.
\end{abstract}

Conclusions: In conclusion, this is a classic case of CLAH with exceptionally small adrenal glands. Q77X mutation seems to be more common in Chinese CLAH patients. Additionally, this is the first report of the growth pattern associated with CLAH after a 15-year follow-up.

Keywords: Congenital lipoid adrenal hyperplasia, Steroidogenic acute regulatory protein, Mutation, Growth

\section{Background}

Congenital lipoid adrenal hyperplasia (CLAH, OMIM 201710 ) is the most severe form of congenital adrenal hyperplasia $(\mathrm{CAH})$ and may cause $46, \mathrm{XY}$ disorders of sex development (DSD). CLAH is an autosomal recessive inherited disorder caused by mutations of the steroidogenic acute regulatory protein (StAR; OMIM 600617) gene [1]. Currently, more than 83 different mutations of the StAR gene have been reported in approximately 190 patients [2]. However, only 17 cases of CLAH have been reported in Chinese patients [3-9]. The clinical features include severe adrenal and gonadal steroidogenesis defects due to disorder of the conversion

\footnotetext{
*Correspondence: su_zhe@126.com

'Department of Endocrinology, Shenzhen Children's Hospital, 7019\# Yitian

Road, Futian District, Shenzhen 518038, Guangdong Province, China

Full list of author information is available at the end of the article
}

of cholesterol to pregnenolone $(\mathrm{P})$. All affected individuals with classic CLAH are phenotypically female regardless of their gonadal sex [1]. Hormone replacement enables long-term survival for these patients, but the literature regarding their long-term outcomes is limited.

Here, we report a 15-year follow-up of a Chinese patient with typical clinical manifestations of CLAH except for small adrenal glands.

\section{Case presentation}

The patient was Chinese individual who was raised as a female. She was born full-term by vaginal delivery. She was the fourth child of nonconsanguineous parents. She was admitted to our hospital at 2 months of age with recurrent vomiting, diarrhea and dehydration. She was found to have hyperpigmentation, hyponatremia

(c) The Author(s). 2018 Open Access This article is distributed under the terms of the Creative Commons Attribution 4.0 International License (http://creativecommons.org/licenses/by/4.0/), which permits unrestricted use, distribution, and 
(sodium $114 \mathrm{mmol} / \mathrm{L}$ ) and hyperkalemia (potassium $6.98 \mathrm{mmol} / \mathrm{L}$ ). The serum adrenocorticotropic hormone (ACTH) level was greater than $1250 \mathrm{pg} / \mathrm{ml}$ accompanied by very low levels of cortisol $(0.17 \mu \mathrm{g} / \mathrm{dl})$ and aldosterone $(4.21 \mathrm{pg} / \mathrm{ml})$. The levels of all adrenal steroids, including testosterone $(\mathrm{T}), \mathrm{P}$, dehydroepiandrosterone sulfate, androstenedione and 17-hydroxyprogesterone, were always nearly undetectable. She was diagnosed with primary adrenal insufficiency and was prescribed hydrocortisone and 9a-fludrocortisone orally [10]. However, her treatment compliance was poor. She often did not take the medications on time or at the recommended dose. She was followed up irregularly. Several episodes of adrenal crisis occurred, and she was admitted again at the age of 13.2 years. On admission, her blood pressure was $90 / 60 \mathrm{mmHg}$, and her height, weight and body mass index (BMI) were $148.7 \mathrm{~cm} \mathrm{(-}$ $1.3 \mathrm{SDS}), 35.3 \mathrm{~kg}(-1.5 \mathrm{SDS})$ and $15.96 \mathrm{~kg} / \mathrm{m}^{2}(-1.0$ SDS), respectively. Hyperpigmentation was found on her tongue, gums, face, trunk, elbows, knees, palms, and soles. The patient was in Tanner stage 1. External female genitalia were observed, including a normalsized clitoris and a normal urethral orifice and vaginal orifice. No palpable gonads were identified in the inguinal or labial regions. No pubic or axillary hair was observed. She had a high ACTH level and lower levels of cortisol, adrenal steroids and aldosterone. She exhibited gonadal dysgenesis, including: 1) high baseline levels of luteinizing hormone $(38.2 \mathrm{mIU} / \mathrm{ml})$ and follicle-stimulating hormone $(68.3 \mathrm{mIU} / \mathrm{ml})$; 2) very low levels of baseline $\mathrm{T}(<0.35 \mathrm{nmol} / \mathrm{L})$ and $\mathrm{T}$ after administration of the human chorionic gonadotropin stimulation test $(0.47 \mathrm{nmol} / \mathrm{L})$; and 3$)$ low levels of anti-Müllerian hormone and Inhibin b. The patient's karyotype was 46 , XY (big Y). Ultrasonography revealed the presence of testes-like masses in the pelvic cavity $(1.4 \mathrm{~cm} \times 0.8 \mathrm{~cm} \times$ $1.0 \mathrm{~cm}$ on the left and $1.5 \mathrm{~cm} \times 0.6 \mathrm{~cm} \times 1.0 \mathrm{~cm}$ on the right). Neither ovaries nor a uterus was identified. After 13 years of steroid replacement therapy, the patient underwent an adrenal computed tomography (CT) scan at the age of 13.2 years. Adrenal CT scans revealed that the adrenal glands on both sides were much smaller than normal (Fig. 1). Magnetic resonance imaging of the abdominal and pelvic cavities showed no uterus or ovaries. The patient's bone age (BA) was 13.5 years old (Fig. 2).

The patient was given hydrocortisone $\left(17.3 \mathrm{mg} / \mathrm{m}^{2}\right.$ of body surface area per day) and $9 a$-fludrocortisone (0.1 mg/day) regularly. Her hyperpigmentation was slightly alleviated, and she had no adrenal crisis episodes thereafter. At the age of 15.2 years, the patient began estrogen replacement therapy. After 4 months of estrogen treatment, her breasts began developing. Photos of the patient are shown in Fig. 3. Laboratory and treatment data were collected during the 15-year follow-up and are shown in Table 1. Growth data are shown in Table 2. Compared to healthy Chinese girls [11], the patient's growth charts were drawn and are shown in Fig. 4. At 15.5 years old, she nearly reached her final adult height $(154 \mathrm{~cm})$, which was similar to her midparent height $(152.5 \mathrm{~cm})$ but shorter than the heights of her two sisters $(156 \mathrm{~cm}, 160 \mathrm{~cm})$.

The patient had no other diseases and exhibited normal intelligence. One of her elder sisters died during infancy from an unknown cause. Her parents and her other two sisters were healthy and underwent normal
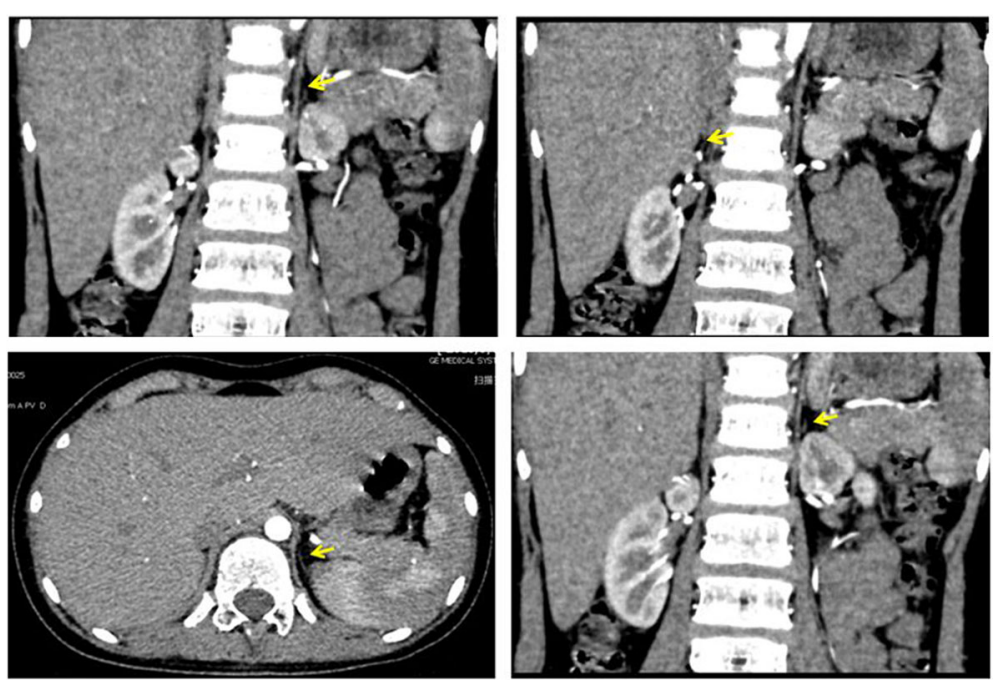

Fig. 1 At the age of 13.2-year adrenal computed tomography (CT) scans revealed that the adrenal glands on both sides were much smaller than normal. The yellow arrows indicate the adrenal gland 


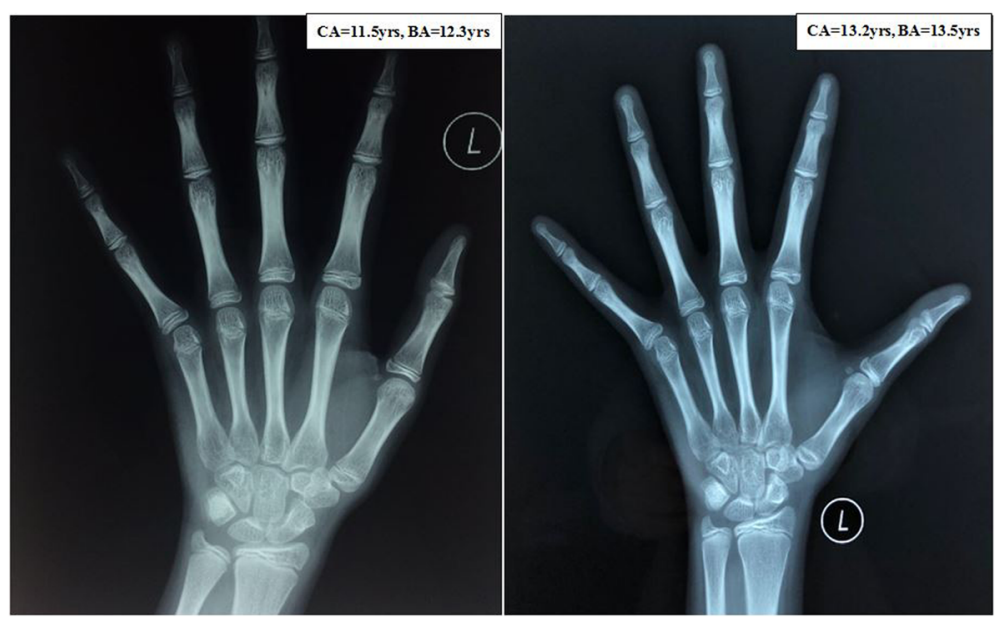

Fig. 2 Bone age of the patient. CA chronological age, BA bone age, yrs. =years old

puberty. Her mother died in a traffic accident when she was 10 years old. No family history of DSD was noted.

Considering the above clinical picture, an initial diagnosis of 46, XY DSD caused by severe deficiency of adrenal and gonadal steroids was established. The most plausible causes of the patient's condition include some specific types of $\mathrm{CAH}$ ( $3 \beta$-hydroxysteroid dehydrogenase deficiency, 17 hydroxysteroid dehydrogenase deficiency, CLAH) and congenital adrenal hypoplasia caused by mutations of the NROB1 or NR5A1 genes [12]. Medical exome sequencing was the method of choice for a clear diagnosis.

\section{Gene analysis}

The sex-determining region on the $\mathrm{Y}$ chromosome gene was positive. Gene sequencing was performed with medical exome sequencing. The interpretation of the sequence variants and pathogenicity was conducted according to guidelines set by the American College of Medical Genetics and Genomics [13]. The Human Gene Mutation Database (HGMD), db SNP database, and 1000 database were used to identify whether the observed mutations have been reported previously. Compound heterozygous mutations were found in the StAR gene, with c. $229 \mathrm{C}>\mathrm{T}$ (p. Q77X) in exon 3 and c.
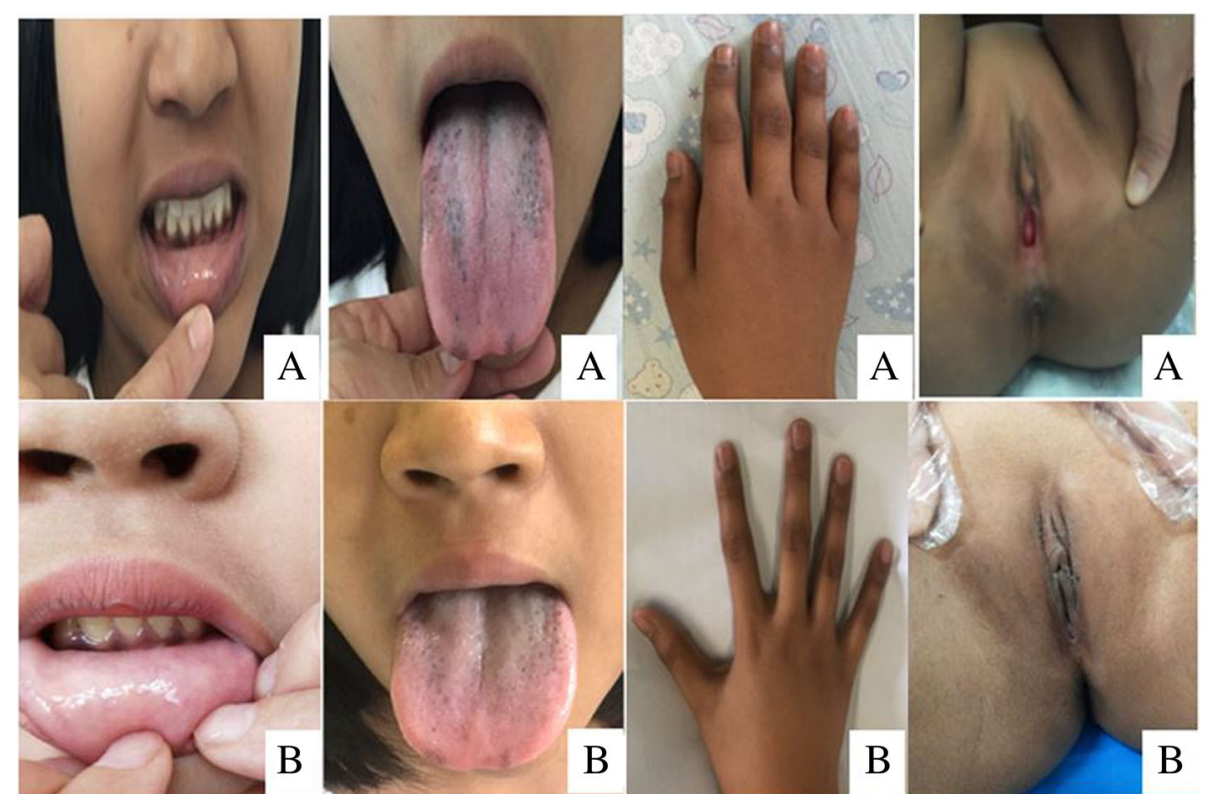

Fig. 3 Photos of the patient with CLAH. (a) Photos at age 13.2 years, (b) Photos at age 15.5 years 


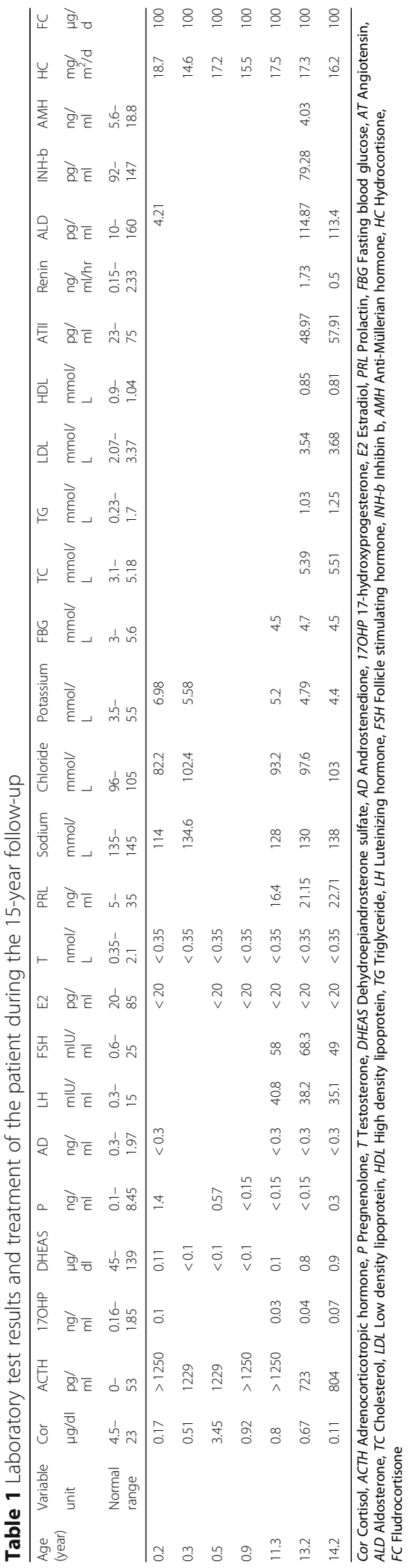


Table 2 Physical assessments of the patient during the 15-year follow-up

\begin{tabular}{|c|c|c|c|c|c|c|}
\hline Age (year) & BA (year) & Height $(\mathrm{cm})$ & $\mathrm{HtSDS}$ & Weight (kg) & WtSDS & BMI $\left(\mathrm{kg} / \mathrm{m}^{2}\right)$ \\
\hline Newborn & & - & & 3.0 & -0.6 & - \\
\hline 0.2 & & 50.0 & 0.2 & 3.7 & 1.1 & 14.80 \\
\hline 0.9 & & 72.5 & -0.5 & 8.6 & -0.1 & 15.27 \\
\hline 1.5 & & 80.0 & -0.5 & 11.0 & 0.3 & 17.19 \\
\hline 1.9 & & 84.0 & -0.1 & 12.0 & 0.5 & 17.01 \\
\hline 3.7 & & 99.0 & -0.1 & 15.5 & 0.2 & 15.81 \\
\hline 4.2 & 5 & 102.0 & -0.3 & 18.0 & 0.9 & 17.30 \\
\hline 10.2 & & 134.0 & -1.0 & 30.5 & -0.2 & 16.99 \\
\hline 11.3 & & 138.8 & -1.2 & 35.2 & -0.1 & 18.27 \\
\hline 11.5 & 12.3 & 139.5 & -1.5 & 36.0 & -0.4 & 18.50 \\
\hline 13.2 & 13.5 & 148.7 & -1.3 & 35.3 & -1.5 & 15.96 \\
\hline 14.2 & & 153.3 & -0.9 & 45.6 & -0.3 & 19.40 \\
\hline 15.2 & 15 & 154.0 & -1.1 & 52.4 & 0.3 & 22.09 \\
\hline 15.5 & & 154.0 & -1.2 & 53.0 & 0.4 & 22.35 \\
\hline
\end{tabular}

HtSDS Height standard deviation score, WtSDS Weight standard deviation score, BMI Body mass index, BA Bone age

722C > T (p. Q258X) in exon 7. The patient's father had the same heterozygous mutation at c. $229 \mathrm{C}>\mathrm{T}$ (p. Q77X) (Fig. 5). Unfortunately, the samples from her mother and her two sisters could not be obtained. No other variants were observed in the CYP11A1, CYP17A1, HSD3ß2, StAR, P450scc, MC2R, NROB1 and NR5A1 genes.

\section{Surgery and gonadal histology}

After discussion with the DSD multidisciplinary team and consent from the patient and her father, the patient underwent surgery at 14.2 years old. Surgical exploration showed no Müllerian structures. Both gonads were removed, and the pathological results indicated hypogenesis of both testes. Hyalinization of the seminiferous tubules, the presence of spermatogonia and spermatocytes, and no sperm or sperm cells in the gonads were noted during the procedure. Immunohistochemical staining of the gonadal tissue was partly positive for CD117 and OCT $3 / 4$ and positive for TSPY1 and Inhibin A (Fig. 6).

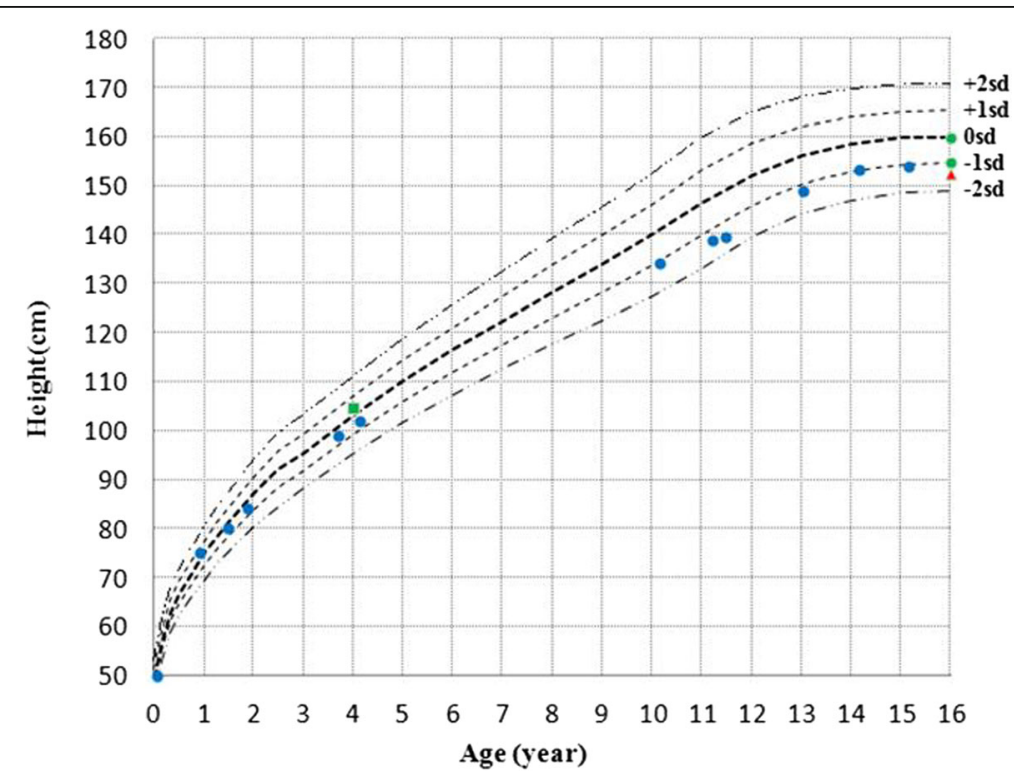

Fig. 4 Chart showing the progression of the patient's height during the 15-year follow-up. Blue dots indicate the patient's height. Green dots indicate the height of the patient's sisters. The red triangle represents the midparent height. The green square represents the height of the patient reported in Fu's paper 


\section{TATCTCTAGCAGGGG ATCAACTAGGTCCTG}
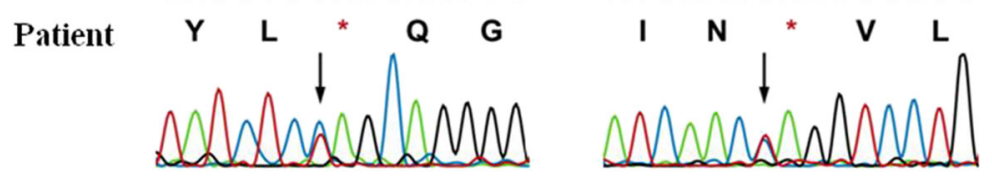

TATCTCTAGCAGGGG

A TCAACCAGG T C CTG

Father
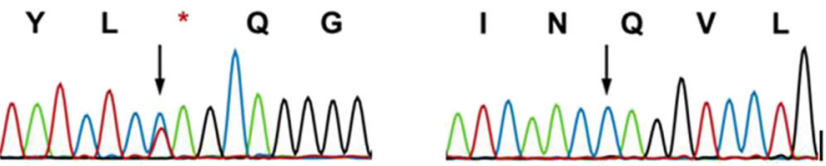

c. $229 \mathrm{C}>\mathrm{T}$ (p. Q77X)

c. 722C > T (p. Q258X)

Fig. 5 Sequence electropherograms showing the StAR gene mutations in the patient and her father. Sequence analysis of the StAR gene revealed two hemizygous nonsense mutations at c. 229C > T ( $p$. Q77X) and c. 722C>T ( $p$. Q258X). The heterozygous mutation of c. 229C > T (p. Q77X) was found in the patient's father. Because the patient's mother had died due to a traffic accident, the mother's sequences could not be tested. The black arrows indicate the hemizygous nucleotides of c. 229C>T (p. Q77X) and c. 722C>T (p. Q258X) from the patient and the heterozygous mutation from the patient's father
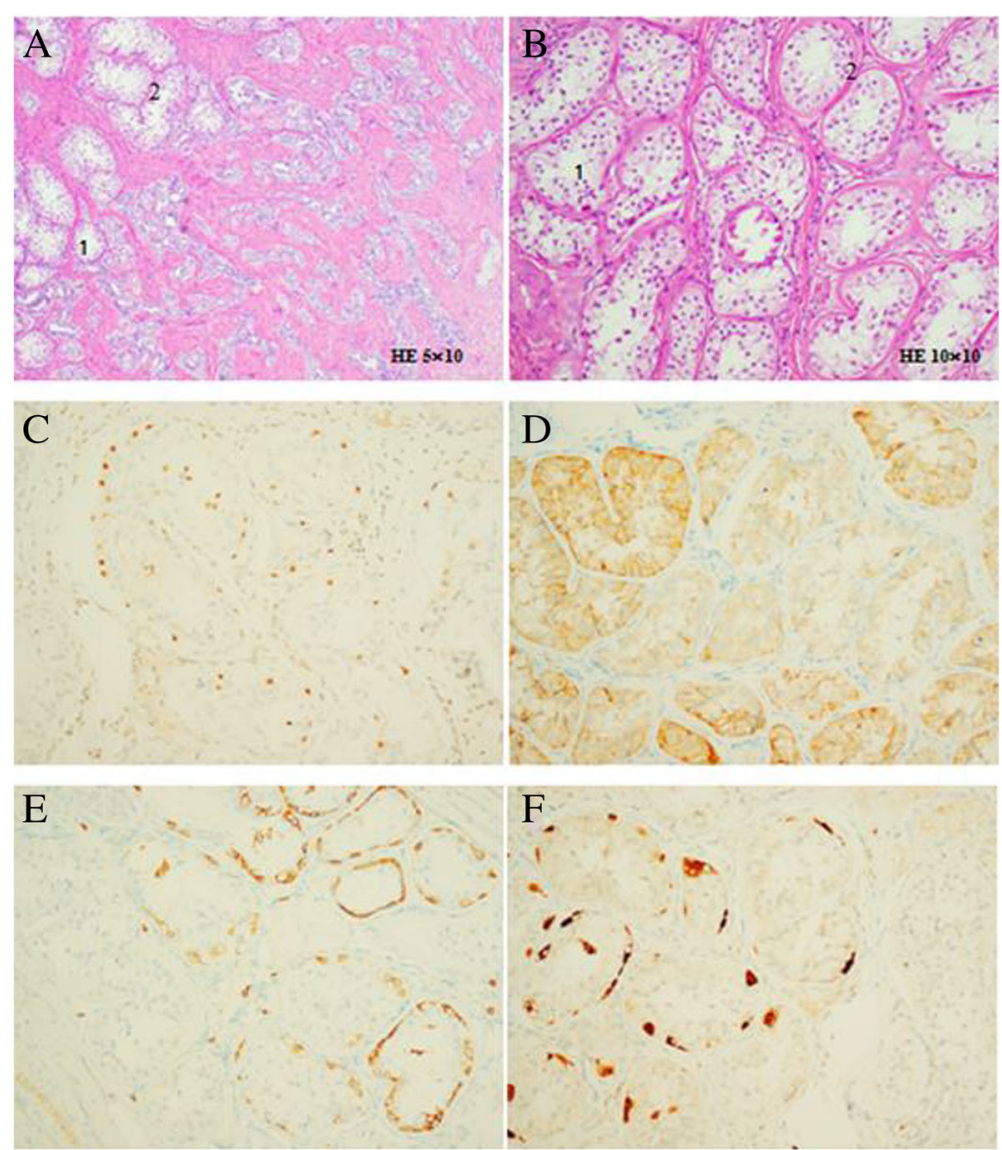

Fig. 6 Histology of the removed gonads. a Testis at low magnification: Seminiferous tubules (1). Hyaline thickening of the basal membranes (2), b Testis at higher magnification: Seminiferous tubules (1). Hyaline thickening of the basal membranes (2). c Testis stained for OCT 3/4. d Testis stained for Inhibin A. e Testis stained for CD117. f Testis stained for TSPY1 


\section{Discussion and conclusion}

$\mathrm{CLAH}$ is an autosomal recessive inherited disorder caused by to mutations in the StAR gene. The human StAR gene is located on chromosome 8p11.2 and consists of 7 exons that translate into a protein of 285 amino acids in length. StAR is required for translocation of cholesterol from the outer to the inner mitochondrial membranes to synthesize P [14] and is involved in the first step of adrenal and gonadal steroidogenesis. Individuals with mutations in this gene may have severe deficiency of adrenal and/ or gonadal steroids accompanied by fatty accumulation in enlarged adrenal glands in most cases. The amino acid sequence of the StAR protein is highly conserved from 67 to 280 [4]. The full length of the protein consists of a mitochondrial target sequence on its $\mathrm{N}$-terminus and a cholesterol-binding site on its C-terminus [15]. In vitro studies have revealed that the StAR protein without the $\mathrm{C}$-terminal region had severe defects in function, while deletion of the $\mathrm{N}$-terminus resulted in less loss-of-function [16].

We presented a case of CLAH caused by mutations in the StAR gene with a 15-year follow-up. This patient exhibited typical features of primary adrenal insufficiency shortly after birth. She was raised as a female and had visibly normal external female genitalia despite the presence of the male sex chromosome. The patient carried compound heterozygous mutations c. $229 \mathrm{C}>\mathrm{T}$ (p. Q77X) and c. $722 \mathrm{C}>\mathrm{T}$ (p. $\mathrm{Q} 258 \mathrm{X})$ in the StAR gene, both of which are nonsense mutations. Q258X is a known pathogenic hotspot mutation in Japanese, Korean and Chinese individuals with CLAH [5, 17]. Deleting 10 amino acids from the C-terminus has been shown to decrease StAR activity by approximately 50\% [18]. With the nonsense mutation p. Q258X, StAR protein activity decreases to $16 \%$ of that of wild-type activity due to truncation of 27 amino acids in the C-terminal region [19].

The other mutation in our patient is c. $229 \mathrm{C}>\mathrm{T}$ (p. Q77X) in exon 3. Q77 is a highly conserved residue from zebrafish (Fig. 7). The nonsense mutation c. 229C > T (p. Q77X) changes glutamine 77 to a terminal codon. Therefore, the StAR protein became truncated to a length much shorter than that of the Q258X mutant and may have exhibited less than $16 \%$ activity. Therefore, the Q77X mutation was predicted to be pathogenic. The Q77X mutation has been previously reported in only two other Chinese patients with CLAH [7, 9]. Therefore, this mutation may be more common in the Chinese population.

The typical features of CLAH are enlarged adrenal glands with lipid deposits [20]. However, a suspected diagnosis of CLAH in the absence of adrenal enlargement cannot be ruled out [21, 22]. Huang et al. [5] studied images of the adrenal glands from CLAH patients and found that 7 of 9 cases had enlarged adrenal glands, one had normal-sized adrenal glands with fatty deposits, and one had normal adrenal glands. Only one CLAH case with small-sized adrenal glands, as observed in our patient, has been reported previously [20] (Table 3); however, the paper provided no corresponding speculation. The physiological mechanism for small adrenal glands remains unclear.

Data regarding the growth patterns of CLAH patients are limited (Table 4). The heights of CLAH patients from 1.2 years to 4 years of age were reported to be between the 10th and 50th percentiles of that among the normal population $[4,23]$. The final heights in patients with CLAH were reported to be shorter or similar to the calculated midparent height $[9,24,25]$. Here, we constructed the first growth curve of a CLAH patient before and after sex hormone replacement. Birth length and heights before age 4 were similar to the average value of the general population. However, her height decreased to approximately -1 SDS at 10 years old. At 15.5 years old, the patient's height was near her final adult height, which was similar to her midparent height but shorter than her two sisters' heights. The patient's BA was similar to her chronological age from age 4 to age 15.2 (Fig. 2), which is different from the retarded BA reported in other cases [24].

Limitations: Growth data in children with CLAH have rarely been analyzed. Our study plotted the patient's anthological measurement data from infancy to adolescence. However, accurate descriptions of growth patterns in children with CLAH require more cases and longer follow-ups.

In conclusion, we identified a CLAH patient with a 15-year follow-up. Small-sized adrenal glands were the
STAR ZEBRAFISH

STAR_MOUSE

STAR_RAT

STAR_SHEEP

STAR PAN TROGLODYTES

STAR HUMAN
SPIAEETYSEADQCYVOQGQFALOKS IS ILFDQDGWQTEIFS INGEKVMSKVLPGIGKVF SQLEATLYSDQELSYIQQGEVAMQKALGILNNQEGWKKESQQENGDEVLSKMVPDVGKVF SQLEATLISDQELSY IQQGEEAMQKALGILNNQEGWKKESQQENGDEVLSKVVPGVGKVF SQLEDSLYSDQELAY IQQGEEAMQRALGILKDQEGWKKESRQVNGDEVLSKVIPDVGKVF SRLEETLYSDQELAYLQQGEEAMQKALGILSNQEGWKKESQQDNGDKVMSKVVPDVGKVF SRLEETLYSDQELAYLOQGEEAMQKALGILSNQEGWKKESQQDNGDKVMSKVVPDVGKVF

Fig. 7 Sequence alignment of the StAR protein from seven species. Q77 is a highly conserved amino acid (highlighted in red) 


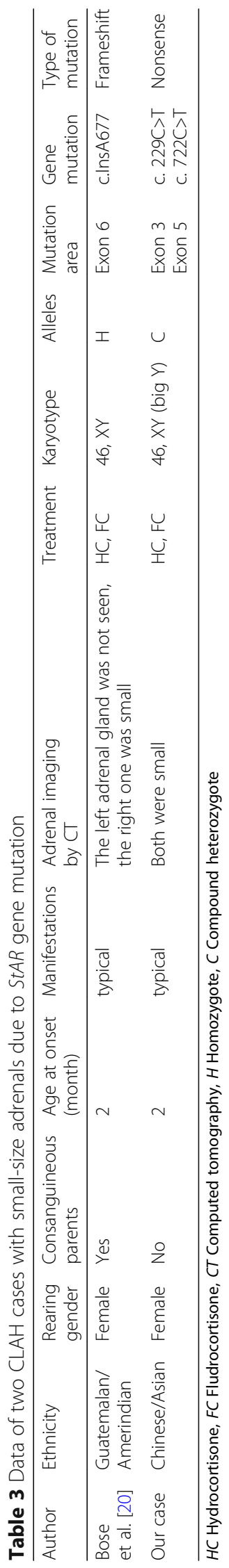


Table 4 Available growth data of CLAH cases due to StAR gene mutations

\begin{tabular}{|c|c|c|c|c|c|c|c|c|c|c|c|c|}
\hline Author & Ethnicity & Relation & $\begin{array}{l}\text { Age at } \\
\text { onset } \\
\text { (month) }\end{array}$ & Manifestations & $\begin{array}{l}\mathrm{Ht} \\
\text { (percentile) }\end{array}$ & $\begin{array}{l}\text { FAH } \\
(\mathrm{cm})\end{array}$ & $\begin{array}{l}\text { FAH } \\
\text { vs MP }\end{array}$ & BA & Treatment & Karyotype & Alleles & Mutation \\
\hline \multirow[t]{2}{*}{$\begin{array}{l}\text { Khoury } \\
\text { et al. [24] }\end{array}$} & $\begin{array}{l}\text { French } \\
\text { Canadian }\end{array}$ & siblings & 11 & typical & NM & NM & similar & $\begin{array}{l}\text { significantly } \\
\text { delayed }\end{array}$ & $\mathrm{HC}, \mathrm{FC}, \mathrm{SH}$ & $46, X Y$ & $\mathrm{H}$ & p.L275P \\
\hline & $\begin{array}{l}\text { French } \\
\text { Canadian }\end{array}$ & siblings & 1.5 & typical & NM & NM & similar & $\begin{array}{l}\text { slightly } \\
\text { delayed }\end{array}$ & $\mathrm{HC}, \mathrm{FC}, \mathrm{SH}$ & $46, X X$ & $\mathrm{H}$ & p.L275P \\
\hline \multirow[t]{2}{*}{$\begin{array}{l}\text { Fluck } \\
\text { et al. [25] }\end{array}$} & Caucasian & siblings & 10 & typical & NM & 143 & low & NM & $\mathrm{HC}, \mathrm{FC}$ & $46, X X$ & C & $\begin{array}{l}\text { p.T44HfsX3 } \\
\text { p.G221S }\end{array}$ \\
\hline & Caucasian & siblings & 14 & typical & NM & 159.5 & similar & NM & $\mathrm{HC}, \mathrm{FC}$ & $46, X Y$ & C & $\begin{array}{l}\text { p.T44HfsX3 } \\
\text { p.G221S }\end{array}$ \\
\hline $\begin{array}{l}\text { Qiu } \\
\text { et al. [9] }\end{array}$ & Chinese & & 1.3 & typical & NM & 152 & low & NM & $\mathrm{HC}, \mathrm{FC}, \mathrm{SH}$ & $46, X Y$ & C & $\begin{array}{l}\text { p.Q77X } \\
\text { c.838delA }\end{array}$ \\
\hline $\begin{array}{l}\text { Fu } \\
\text { et al. [4] }\end{array}$ & Chinese & & 11 & typical & $\begin{array}{l}\text { P50th } \\
\text { (4 years) }\end{array}$ & NM & NM & NM & $\mathrm{HC}, \mathrm{FC}$ & $46, X Y$ & H & p.K236Tfs $* 47$ \\
\hline \multirow[t]{2}{*}{$\begin{array}{l}\text { Park } \\
\text { et al. [23] }\end{array}$} & Korean & twins & 1.3 & typical & $\begin{array}{l}\text { P3-10th } \\
\text { (14 months) }\end{array}$ & NM & NM & NM & $\mathrm{HC}, \mathrm{FC}$ & $46, X X$ & C & $\begin{array}{l}\text { p.R182C } \\
\text { p.Q258X }\end{array}$ \\
\hline & Korean & twins & $<1$ & typical & $\begin{array}{l}\text { P10-25th } \\
\text { (14 months) }\end{array}$ & NM & NM & NM & $\mathrm{HC}, \mathrm{FC}$ & $46, X X$ & C & $\begin{array}{l}\text { p.R182C } \\
\text { p.Q258X }\end{array}$ \\
\hline Our case & Chinese & & 2 & typical & $\begin{array}{l}\text { P25-50th } \\
\text { (18 months) } \\
\text { P25th } \\
\text { ( } 4.2 \text { years) }\end{array}$ & 154 & similar & NM & $\mathrm{HC}, \mathrm{FC}, \mathrm{SH}$ & $46, X Y$ & C & $\begin{array}{l}\text { p.Q77X } \\
\text { p.Q258X }\end{array}$ \\
\hline
\end{tabular}

HC Hydrocortisone, FC Fludrocortisone, SH Sex hormone, CT Computed tomography, Al Adrenal insufficiency, GD Gonadal dysplasia, BA Bone age, NM No mention, $H$ Homozygote, $C$ Compound heterozygote, E Estradiol

primary characteristic in our patient. Based on her long-term follow-up, her growth profile is the first reported growth pattern of CLAH. Our patient is the third reported case with the Q77X mutation in the StAR gene, which seems to be more common in the Chinese population.

\section{Abbreviations}

ACTH: Adrenocorticotropic hormone; AHC: Adrenal hypoplasia, congenital; BA: Bone age; BMI: Body mass index; CLAH: Congenital lipoid adrenal hyperplasia; CT: Computed tomography; DSD: Disorders of sex development; P: Pregnenolone; SDS: Standard deviation score; SF-1: Steroidogenic factor-1; StAR: Steroidogenic acute regulatory protein; T: Testosterone

\section{Acknowledgments}

The authors thank the patient and her father for their participation in this study and their consent to report these findings and pictures.

\section{Funding}

This research did not receive any specific grant from any funding agency in the public, commercial or not-for-profit sector.

\section{Availability of data and materials}

The dataset analyzed during the current study are available from the corresponding author upon reasonable request.

\section{Authors' contributions}

XZ contributed to the data collection, data interpretation and writing of the report. ZS contributed to the study design and reviewed the report. JMS contributed to the histology data collection and data interpretation. YGG contributed to the imaging data collection and data interpretation. PQW contributed to the gene mutation interpretation. SLL contributed to the surgical data collection. XL contributed to the data collection and study conception and design. LW contributed to the growth data collection, data interpretation and revision of the report. LLP contributed to the photo data collection, image processing of the report and revision of the report. All authors read and approved the final manuscript.

\section{Ethics approval and consent to participate}

This study was approved by ethical committee of Shenzhen Children's Hospital. All data and pictures in the study were permitted with consent from the patient and her father.

\section{Consent for publication}

Written consent for publication of images was given by the patient's father.

\section{Competing interests}

The authors declare that they have no competing interests.

\section{Publisher's Note}

Springer Nature remains neutral with regard to jurisdictional claims in published maps and institutional affiliations.

\section{Author details}

'Department of Endocrinology, Shenzhen Children's Hospital, 7019\# Yitian Road, Futian District, Shenzhen 518038, Guangdong Province, China. 2Pathology Department, Shenzhen Children's Hospital, Shenzhen 518038, China. ${ }^{3}$ Radiology Department, Shenzhen Children's Hospital, Shenzhen 518038, China. ${ }^{4}$ Pediatrics Research Institute, Shenzhen Children's Hospital, Shenzhen 518038, China. ${ }^{5}$ Department of Urology, Shenzhen Children's Hospital, Shenzhen 518038, China.

Received: 24 May 2018 Accepted: 15 October 2018

Published online: 06 November 2018

\section{References}

1. Hauffa BP, Miller WL, Grumbach MM, Conte FA, Kaplan SL. Congenital adrenal hyperplasia due to deficient cholesterol side-chain cleavage activity $(20,22$-desmolase) in a patient treated for 18 years. Clin Endocrinol. 1985;23:481-93. 
2. Kaur J, Casas L, Bose HS. Lipoid congenital adrenal hyperplasia due to STAR mutations in a Caucasian patient. Endocrinol Diabetes Metab Case Rep. 2016;2016:150119

3. Lihong W, Lei W, Yanhua S, Qinfang W, Mei F, Gaixiu Z, et al. A case report of congenital lipoid adrenal hyperplasia and literature review. Chin J Med. 2017:52:92-6.

4. Fu R, Lu L, Jiang J, Nie M, Wang X, Lu Z. A case report of pedigree of a homozygous mutation of the steroidogenic acute regulatory protein causing lipoid congenital adrenal hyperplasia. Medicine (Baltimore). 2017:96:e6994.

5. Huang Z, Ye J, Han L, Qiu W, Zhang H, Yu Y, et al. Identification of five novel STAR variants in ten Chinese patients with congenital lipoid adrenal hyperplasia. Steroids. 2016;108:85-91.

6. Xie T, Zheng JP, Huang YL, Fan C, Wu DY, Tan MY, et al. Clinical features and StAR gene mutations in children with congenital lipoid adrenal hyperplasia. Zhongguo Dang Dai Er Ke Za Zhi. 2015;17:472-6.

7. Ruimin C, Xin Y, Ying Z, Xiaohong Y, Xiangquan L. Mutation analysis of steroid acute regulatory protein gene in a patient affected with congenital lipoid adrenal hyperplasia. Chinese J Endocrinol Metab. 2014; 30:980-4.

8. Shiqin L, Huicui Y, Linqi C, Wenxiang W, Haiying W, Fengyun WY, et al. case report of lipoid congenital adrenal hyperplasia. J Appl Clin Pediatr. 2010;25:263-4.

9. Qiu WJ, Ye J, Han B, Han LS, Gu XF. Molecular genetic analysis of congenital lipoid adrenal hyperplasia. Zhonghua Er Ke Za Zhi. 2004;42:585-8.

10. Oelkers W. Adrenal insufficiency. N Engl J Med. 1996;335:1206-12.

11. Li H, Ji CY, Zong XN, Zhang YQ. Height and weight standardized growth charts for Chinese children and adolescents aged 0 to 18 years. Zhonghua Er Ke Za Zhi. 2009:47:487-92.

12. Houk CP, Lee PA. Consensus statement on terminology and management: disorders of sex development. Sex Dev. 2008;2:172-80

13. Boehm U, Bouloux PM, Dattani MT, de Roux N, Dode C, Dunkel L, et al. Expert consensus document: European consensus statement on congenital hypogonadotropic hypogonadism--pathogenesis, diagnosis and treatment. Nat Rev Endocrinol. 2015;11:547-64.

14. Lin D, Sugawara T, Strauss JR, Clark BJ, Stocco DM, Saenger P, et al. Role of steroidogenic acute regulatory protein in adrenal and gonadal steroidogenesis. Science. 1995;267:1828-31.

15. Sugawara T, Lin D, Holt JA, Martin KO, Javitt NB, Miller WL, et al. structure of the human steroidogenic acute regulatory protein (StAR) gene: StAR stimulates mitochondrial cholesterol 27-hydroxylase activity. BiochemistryUs. 1995;34:12506-12.

16. Miller WL. Androgen biosynthesis from cholesterol to DHEA. Mol Cell Endocrinol. 2002;198:7-14.

17. Kim JM, Choi JH, Lee JH, Kim GH, Lee BH, Kim HS, et al. High allele frequency of the P.Q258X mutation and identification of a novel missplicing mutation in the STAR gene in Korean patients with congenital lipoid adrenal hyperplasia. Eur J Endocrinol. 2011;165:771-8.

18. Arakane F, Sugawara T, Nishino H, Liu Z, Holt JA, Pain D, et al. Steroidogenic acute regulatory protein (StAR) retains activity in the absence of its mitochondrial import sequence: implications for the mechanism of StAR action. Proc Natl Acad Sci U S A. 1996;93:13731-6.

19. Kang E, Kim YM, Kim GH, Lee BH, Yoo HW, Choi JH. Mutation spectrum of STAR and a founder effect of the P.Q258* in Korean patients with congenital lipoid adrenal hyperplasia. Mol Med. 2017;23:149-54.

20. Bose HS, Sato S, Aisenberg J, Shalev SA, Matsuo N, Miller WL. Mutations in the steroidogenic acute regulatory protein (StAR) in six patients with congenital lipoid adrenal hyperplasia. J Clin Endocrinol Metab. 2000;85: 3636-9.

21. Hashemipour M, Ghasemi M, Hovsepian S. a case of congenital lipoid adrenal hyperplasia. Int J Prev Med. 2012;3:510-4.

22. Sahakitrungruang $T$, Soccio RE, Lang-Muritano M, Walker JM, Achermann JC, Miller WL. Clinical, genetic, and functional characterization of four patients carrying partial loss-of-function mutations in the steroidogenic acute regulatory protein (StAR). J Clin Endocrinol Metab. 2010;95:3352-9.

23. Park HW, Kwak BO, Kim GH, Yoo HW, Chung S. P.R182C mutation in Korean twin with congenital lipoid adrenal hyperplasia. Ann Pediatr Endocrinol Metab. 2013;18:40-3.
24. Khoury K, Barbar E, Ainmelk Y, Ouellet A, Lavigne P, LeHoux JG. Thirty-eightyear follow-up of two sibling lipoid congenital adrenal hyperplasia patients due to homozygous steroidogenic acute regulatory (STARD1) protein mutation. Molecular structure and modeling of the STARD1 L275P mutation. Front Neurosci. 2016;10:527.

25. Fluck CE, Pandey AV, Dick B, Camats N, Fernandez-Cancio M, Clemente M, et al. Characterization of novel StAR (steroidogenic acute regulatory protein) mutations causing non-classic lipoid adrenal hyperplasia. PLoS One. 2011;6:e20178.

\section{Ready to submit your research? Choose BMC and benefit from:}

- fast, convenient online submission

- thorough peer review by experienced researchers in your field

- rapid publication on acceptance

- support for research data, including large and complex data types

- gold Open Access which fosters wider collaboration and increased citations

- maximum visibility for your research: over $100 \mathrm{M}$ website views per year

At BMC, research is always in progress.

Learn more biomedcentral.com/submissions 